\title{
AN EXPLORATION OF EXPLICIT AND IMPLICIT LEARNING OF RULES BY ENGLISH SECOND LANGUAGE LEARNERS
}

\author{
Diana Ayliff \\ Nelson Mandela Metropolitan University
}

This article addresses the issue of whether second language learners of English can benefit from explicitly taught rules. It describes research carried out on 264 South African respondents at the Nelson Mandela Metropolitan University - hereafter referred to as NMMU (previously known as the University of Port Elizabeth), some of whom were first and some second language speakers of English. The research replicates in a multilingual environment one done by Green and Hecht (1992) in which twelve errors commonly committed by German learners of English were given to 300 respondents at various levels from school pupils to university students. It was found that the South African respondents were less likely than the German ones to be able to articulate rules of grammar and also less able to correct the errors. If they were able to state which rule of grammar had been broken they were almost always able to correct the error.

\section{INTRODUCTION}

Relatively few empirical studies have explored the relationship between explicit and implicit knowledge of rules of grammar amongst second language learners of English. The question of whether knowing a rule increases the accuracy of the learners' performance was the broad research aim of the study reported in this article. It was part of a broader study that investigated the efficacy of advanced learners of English focusing on form.

Green and Hecht's study (1992) of explicit and implicit learning is one of the most significant studies in this field of research and has been discussed by Rod Ellis (1994a, 1994b, 1997), Robinson (1996) and Schmidt (1994) amongst others. Green and Hecht's study is of importance to the current interest in form-focused instruction in second language teaching because of the kind of questions it raises relating to whether learners can benefit from being taught rules, and the detailed and systematic way in which these questions are addressed. Of relevance, for instance, to this paper are the following questions asked by Green and Hecht: Are learners able to recognise where rules they have been taught are applied? Do learners who have an explicit knowledge of rules perform better than those who do not? Does an explicit knowledge of rules help them recognise errors? Are some rules easier to learn and apply than others?

In order to explore the main research question, namely whether knowing a rule increases the accuracy of the learners' performance, the following more specific hypotheses have been posed: 
a) Some rules are more difficult to learn than others.

b) Explicit knowledge of rules helps adult L2 learners produce more target-like structures in English.

c) Fewer L1 speakers than L2 learners will have explicit knowledge of rules, but the L1s will perform better than L2s in correcting errors.

\section{IMPLICIT AND EXPLICIT KNOWLEDGE: A DEFINITION}

The terms implicit and explicit are generally used by most researchers to mean 'unconscious' and 'conscious' knowledge. In both this article and in Green and Hecht's study the terms are used in a way that equates them with Krashen's $(1982,1985)$ distinction between acquisition (implicit knowledge) and learning (explicit knowledge).

\section{GREEN AND HECHT'S (1992) EXPLORATION OF THE EFFICACY OF LEARNING LANGUAGE RULES}

In this paper the main focus is the nature of the relationship between implicit and explicit rules and, most importantly, 'do [rules] help the learners to get the language right?' (Green \& Hecht, 1992: 178). They tested 300 respondents, 250 of whom were L1 German speakers and 50 L1 English speakers. The German speakers' exposure to English had consisted of between three and twelve years of formal teaching. The respondents were divided into four groups for testing, with a control group of 50 English pupils at a comprehensive school in England, as indicated in Table 1 below.

Table 1: Breakdown of respondents by experience and school type

\begin{tabular}{|c|c|c|c|c|c|}
\hline & \multicolumn{3}{|c|}{ German school } & \multirow{2}{*}{$\begin{array}{l}\text { German } \\
\text { university }\end{array}$} & \multirow{2}{*}{$\begin{array}{l}\text { English } \\
\text { pupils }\end{array}$} \\
\hline & Beginners & Intermediate & Advanced & & \\
\hline & $3-4 *$ & $5-6^{*}$ & $8-9 *$ & $11-12 *$ & $\begin{array}{l}3^{\text {rd }} / 4^{\text {th }} \text { year } \\
\text { secondary }\end{array}$ \\
\hline $\begin{array}{l}\text { Gymnasium } \\
\text { (academic) }\end{array}$ & 50 & 50 & 50 & 50 & 50 \\
\hline $\begin{array}{l}\text { Realschule } \\
\text { (technical/ } \\
\text { commercial) }\end{array}$ & & 50 & & & \\
\hline $\begin{array}{l}\text { Hauptschule } \\
\text { (non-academic) }\end{array}$ & & 50 & & & \\
\hline Totals & 50 & 150 & 50 & 50 & 50 \\
\hline
\end{tabular}

The respondents were given a grammaticality task of 12 sentences, each with an error underlined, for example "As you know lives my aunt on a farm and Most of the time I've played tennis". The entire test is given in Appendix A. They had to correct the error and state the rule that had been violated. The L1 English speakers were able to correct the errors $96 \%$ of the time, while the German learners averaged $78 \%$ on the correction task. The range, however, for the scores of the German learners was large. The mean was $33 \%$ at the Hauptschule to a high mean of $97 \%$ for the university students - a range of $64 \%$. Green and 
Hecht (1992) found that the rule could only be stated correctly less than half of the time for both the German and English learners. The German speakers scored a mean of $46 \%$ and the English $42 \%$. Again, there was a very large range amongst the German groups from $7 \%$ at the Hauptschule to $85 \%$ for the university students - a range of $78 \%$. They found, also, that if learners were able to articulate a rule correctly, they were almost always able to do the correction properly.

Another significant finding was that some rules were easier to learn and correct than others. The rules that were most consistently stated correctly were referred to as the "easy" rules, while those that were most seldom correctly stated were termed the "hard" rules (Green \& Hecht, 1992). Easy rules were those that could be applied mechanically and did not depend on large contexts, and hard rules were those that depended on larger structural contexts and involved aspect.

\section{THE EFFICACY OF LEARNING LANGUAGE RULES}

As noted above the main question in Green and Hecht's 1992 study was whether knowing the rules helps the L2 learners approximate the target language more accurately and thus perform better. My research as set out below was conducted to explore the same question.

\section{RESPONDENTS}

The tests were given to a total of 264 respondents of whom 237 were L2 learners of English and 27 L1 English speakers. All were undergraduate university students registered for various courses at NMMU and all were also registered for a course in English. They were divided into three groups:

a) Group 1 comprised 140 first year students who had almost completed a semester course in Practical English in which they had been taught by means of a form-focused approach. All the respondents in this group had passed English as a second language at grade 12 level.

b) Group 2 comprised 64 third year education students following an English course designed for students aiming to become teachers in the junior and intermediate phase (grades 1-7). All the respondents in this group had passed English as a second language at grade 12 level.

c) Group 3 comprised 60 first year students studying a professional / business course in English. Most of these students were aiming to go into the legal profession. Amongst this group were the 27 English L1 respondents. Although all the others in this group were L2 speakers of English, they were proficient in English and had passed English as a first language at grade 12 level.

\section{SCORING PROCEDURE AND MATERIALS}

The test was identical to that of Green and Hecht (1992) described above and the scorers followed the same procedure as described by Green and Hecht in order to allow for optimum comparability. 
The scoring procedure, in brief, was as follows:

a) Firstly, an accurate rule might be expressed in more or less technical language, for example, (item 11): Relative pronouns referring to a person and in the nominative have the form who or that.

b) Secondly, the metalanguage might be partly inaccurate without impairing the validity of the rule, for example, (item 12): $a$ if the subject does not begin with a vowel, $a n$ if the subject begins with a vowel.

c) Thirdly, the rule might be more or less general, for example, (item 7): For questions and negation the some of a declarative sentence becomes any. We won't: negation! Anything.

d) Fourthly, the rule might be correct but not applicable to the item, for example, (item 7): In questions any is required.

e) Fifthly, the rule might be expressed as a rule of thumb, well known to German pupils and teachers but not obvious to an outsider without explanation, for example, (item 1): SPO (= subject, predicate, object).

f) Sixthly, the rule might express the essential concept, and be associated with a correct correction, but contain a technical flaw (or slip), for example, (item 2): An action completed in the past is expressed by present tense.

g) Lastly, the essential concept might appear to have been grasped even though the correction was incorrect, for example, (item 6): Because he knows him now and knew him before (correction $=$ I'm knowing).

All of the above, with the exception of the fourth, were accepted by Green and Hecht. This relatively liberal acceptance of rule description was replicated in the present research described in this article.

\section{RESULTS}

The results of this research confirm, in general, those found in the Green and Hecht study. The scores achieved by the L2 South African students are considerably lower than those of the German students, but the overall trends found by Green and Hecht are validated by this research. The native English speakers achieved $94 \%$ in their ability to correct the sentences, which compares well with the average score of $96 \%$ of the English pupils in the Green and Hecht study. The L1 English speakers in the present study, however, were first year university students, while those in the Green and Hecht study were school pupils roughly equivalent in age to our grade 10 pupils.

In Graph 1 on the next page the mean scores for the different groups are shown. 
Graph 1: Differences between South African and German groups

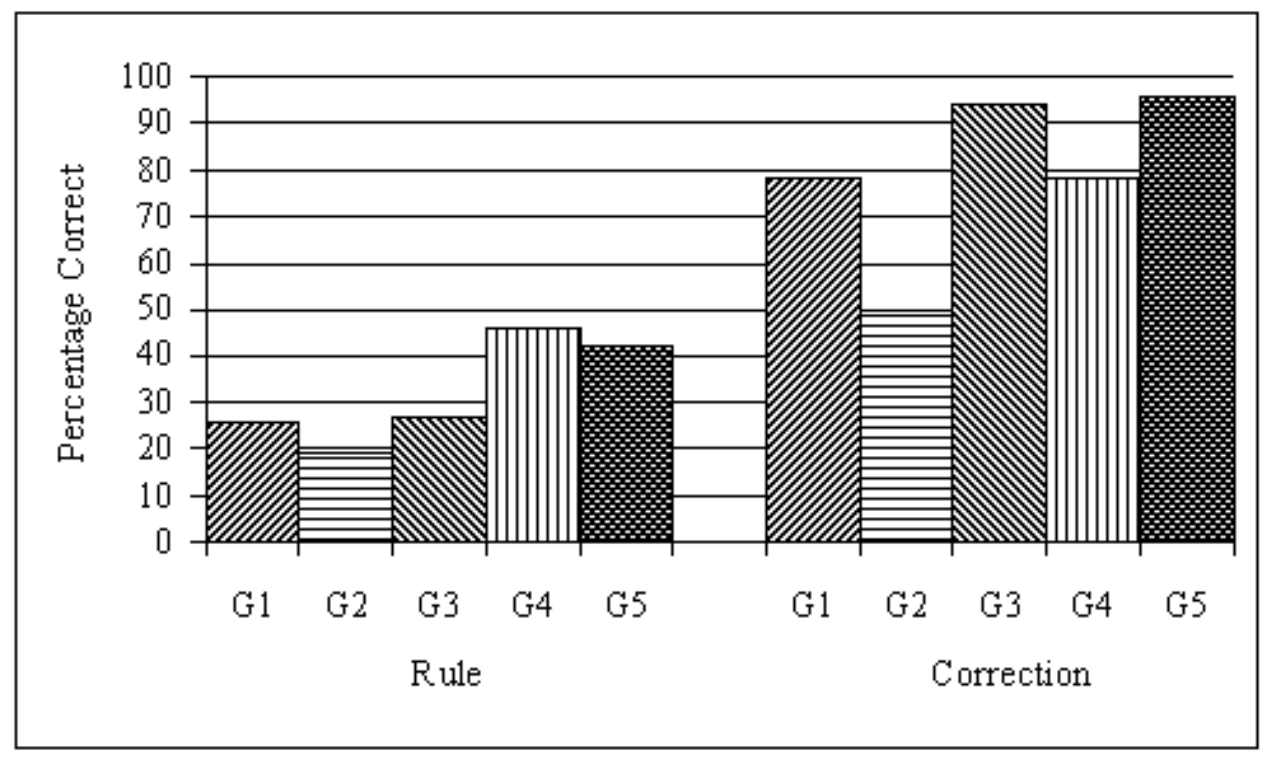

G1: Experimental Group (L2 form-focused course)

G2: Group 2 (L2 teachers' English course)

G3: Group 3 (L1 professional English course)

G4: All German respondents (L2 English)

G5: L1 English school pupils

\section{DISCUSSION OF FINDINGS OF THE PRESENT STUDY}

\section{Some rules are more difficult to learn than others}

It would seem that the results of the present study confirm the findings of the Green and Hecht study and that some rules are more difficult to learn than others. Table 2 below shows the four highest-scoring (+) and the four lowest-scoring (-) rules and corrections tested in the study.

Table 2: High (+) and low (-) scoring rules and corrections in the present study

\begin{tabular}{|c|c|c|c|c|c|c|c|}
\hline & & \multicolumn{3}{|l|}{ Rules } & \multicolumn{3}{|c|}{ Corrections } \\
\hline & & $\begin{array}{l}\text { Practical } \\
\text { English } \\
\text { Students } \\
\text { (Group 1) }\end{array}$ & $\begin{array}{l}\text { Education } \\
\text { students } \\
\text { (Group 2) }\end{array}$ & $\begin{array}{l}\text { L1 Prof./ } \\
\text { Bus. } \\
\text { Students } \\
\text { (Group 3) }\end{array}$ & $\begin{array}{l}\text { Practical } \\
\text { English } \\
\text { Students } \\
\text { (Group 1) }\end{array}$ & $\begin{array}{l}\text { Education } \\
\text { students } \\
\text { (Group 2) }\end{array}$ & $\begin{array}{l}\text { L1 Prof./ } \\
\text { Bus. } \\
\text { Students } \\
\text { (Group 3) }\end{array}$ \\
\hline $\mathrm{N}$ & & 140 & 64 & 60 & 140 & 64 & 60 \\
\hline Item & & $\%$ & $\%$ & $\%$ & $\%$ & $\%$ & $\%$ \\
\hline 1 & S-P order & & & + & & & \\
\hline 2 & past & & & & - & - & - \\
\hline 3 & future & + & + & & + & + & + \\
\hline 4 & do-neg & - & & - & & & \\
\hline 5 & gerund & - & - & - & & & - \\
\hline 6 & perfect & & - & - & - & - & - \\
\hline 7 & some/any & - & - & & - & - & \\
\hline 8 & adverb & - & & & & + & \\
\hline 9 & aspect + & + & + & + & + & + & + \\
\hline 10 & aspect - & & - & - & - & - & - \\
\hline 11 & who/which & + & + & + & + & + & + \\
\hline 12 & $a / a n$ & + & + & + & + & & + \\
\hline
\end{tabular}


The easiest rules to articulate by the SA respondents were those for items 9, (aspect - was coming), 11 (who / which) and 12 (a-form before consonants). These were followed by the rule for item 3 (will - shows futurity). By comparison, the most difficult rules to articulate were for items 4 (do-neg.), 5 (gerund), 6 (present perfect) and 7 (some/any) that were correctly stated by between $2 \%$ and $5 \%$ for the L 2 speakers. The L1s also fared badly on these rules, especially for items 4,5 and 6 , all of which elicited a nil result. Item 10 was another difficult rule to formulate, with a mere $9 \%$ correct response for the L2s and $10 \%$ for the L1s.

The easiest corrections for the L2 SA respondents were items 3 (will), 11 (who/which), 8 (adverb) and 1 (S-P order) that elicited between $78 \%$ and $94 \%$ correct responses. For the L1s all the items were relatively easy with 3 (will) and 11 (who/which) eliciting a 100\% correct response. The most difficult corrections for the L2s in the present study were items 10 (aspect-), 6 (perfect), 2 (past) and 7 (some/any) that received between $31 \%$ and $51 \%$ correct responses. The most difficult correction for the L1s was item 10 (aspect-) with $81 \%$ correct corrections, but, in general, the L1s in the study achieved a high 94\% average for the corrections.

\section{Explicit knowledge of rules helps adult L2 learners of English}

Table 3 shows the relationship between the rules and corrections for the test. Row 1 shows that if respondents were able to articulate rules they were always able to produce a correct correction. Row 2 shows how often, on average, a respondent was able to produce a correct correction despite not being able to articulate the rule correctly. In this study it is shown that if the respondents are able to produce a correct rule they will also produce a correct correction, although one must remember that some of these success rates were extremely low such as the mean of only $23 \%$ achieved by G2 (graph 1). This study confirms the results of the Green and Hecht study in which the L2 respondents were able to give correct corrections $97 \%$ of the time if they could produce a correct rule, and the L1s were able to give corrections $100 \%$ of the time. In both studies it was found that the respondents were far more successful at effecting correct corrections than in producing correct rules.

Table 3: Percentage Correct Corrections according to Correctness of Rule

\begin{tabular}{|l|l|l|l|l|}
\hline & \multicolumn{2}{|l|}{$\begin{array}{l}\text { L2 English } \\
\text { at grade 12 level }\end{array}$} & $\begin{array}{l}\text { L1 English } \\
\text { at grade 12 } \\
\text { level }\end{array}$ \\
\hline & $\begin{array}{l}\text { Practical English } \\
\text { students } \\
\text { (Group 1) }\end{array}$ & $\begin{array}{l}\text { Education } \\
\text { students } \\
\text { (Group 2) }\end{array}$ & $\begin{array}{l}\text { All L2 } \\
\text { (Groups 1 \& 2) }\end{array}$ & $\begin{array}{l}\text { Prof/ Business } \\
\text { Students } \\
\text { (Group 3) }\end{array}$ \\
\hline Correct Rule & $100 \%$ & $100 \%$ & $100 \%$ & $100 \%$ \\
\hline Incorrect Rule & $70 \%$ & $39 \%$ & $60 \%$ & $92 \%$ \\
\hline
\end{tabular}

\section{L1 speakers' vs L2 Learners' knowledge of rules and their performance}

The hypothesis c, posited at the beginning of this paper, namely that fewer L1 speakers than L2 learners will have explicit knowledge of rules, but that the L1s will perform better than the L2s in correcting the errors is only marginally proved. L1 English speakers had explicit knowledge of rules only $23 \%$ of the time, but they did perform better than the L2s in correcting the errors. The L2 learners, however, only marginally outperformed them in the 
rule articulation task by obtaining $25 \%$ for those who had passed English as L2 in grade 12 and 24\% for those who had passed English as L1 at grade 12 level. In the correction task the hypothesis is confirmed and the L2 learners did less well by obtaining only $76 \%$ compared to the $95 \%$ and $93 \%$ scored by the native English speakers and those who had passed grade 12 at English L1 level.

\section{CONCLUSION}

During the last quarter of the 20th century there was a swing away from the explicit teaching of grammar rules as the bias toward communicative approaches to teaching an L2 took hold. Influenced by the ideas of such linguists as Brumfit and Johnson (1979), Littlewood (1981) and Richards and Rogers (1986), the emphasis on message focus often led to a neglect of form. In this research it is shown that the L2 SA respondents in this study are less likely than their German counterparts to be able to articulate rules of grammar and are also less well equipped to correct the errors focused on in the test.

The relationship between the ability to state a correct rule and get the correction right is a complex one. The L1 respondents in both studies seem to be able to correct the inaccuracies implicitly, as may be attested to by several nil responses to the rule articulation, but there was a high rate of accuracy in their corrections. By contrast, amongst the L2 respondents there is a closer correlation between the ability to state the rule and the ability to correct the error. This seems to suggest that a greater emphasis on the form of the language, at least amongst high school and adult learners, might result in more accurate written discourse. The number of recent articles investigating focus on form, noticing and consciousness-raising such as those by Ellis, Basturkmen and Loewen (2001, 2003), Lyster (1998), Oliver (2000), Sheen (2003), Seedhouse (1997) and Williams (1999), as well as those found in Doughty and Williams (1998) attest to this. In addition there is much discussion on these topics in Cook (2001) and Rod Ellis (1997).

In my experience, most advanced L2 learners at tertiary level are eager to understand and learn explicit rules. Many learners claim never to have been taught much explicit grammar at school level and feel frustrated because of a lack of understanding as to why they are making errors. Clearly, as recommended by Green and Hecht, there needs to be a better balance between the time devoted to the teaching of explicit rules and the time devoted to meaningfocused activities.

In both the present study and that by Green and Hecht, it is shown that if the respondents are able to articulate the rule, the likelihood of their being able to correct the error is extremely high. This does not suggest that an attempt should be made to teach all grammar rules. They are far too numerous and complex and much that we learn in an L2 is done implicitly. The question of which rules should be taught is an ongoing debate. In this investigation the rules that were found to be easy to formulate and to apply correctly were those that fell into clear categories and could be applied mechanically. For example the a/an and who/which dichotomies were easily mastered, while the do-neg, gerund and present perfect corrections that were dependent on larger contexts were difficult to master. Observing the conventions of standard syntactical and morphological practices is an integral part in performing well in formal contexts such as academic and professional written discourses. A balance must obviously be achieved between teaching selected formal aspects of an L2 and communicative exposure of learners to academic discourse. 
The findings in this study are a clear indication that we should be teaching some of the hard rules to our L2 secondary school and tertiary learners explicitly. By focusing more on form than has been the practice during the last quarter of a century we are very likely to improve the precision of our L2 learners in their written English.

Clearly, though, research at other institutions in South Africa could be usefully undertaken to strengthen or test this finding. In particular, it could be useful to devise a test based on the common errors of a particular group of South African respondents.

\section{REFERENCES}

BRUMFIT, CJ \& K JOHNSON. 1979. The communicative approach to language teaching. Oxford: Oxford University press.

COOK, V. 2001. Second language learning and language teaching ( $3^{\text {rd }}$ edition). London: Hodder.

DOUGHTY, C \& J WILLIAMS (Eds). 1998. Focus on form in the classroom second language acquisition. Cambridge: Cambridge University Press.

ELLIS, N (Ed). 1994. Implicit and explicit learning of languages. London: Academic Press.

ELLIS, R. 1994a. The study of second language acquisition. Oxford: Oxford University Press.

ELLIS, R. 1994b. A theory of instructed second language acquisition. In Ellis N (ed), Implicit and explicit learning of languages. London: Academic Press.79-114.

ELLIS, R. 1997. SLA research and language teaching. Oxford: Oxford University Press.

ELLIS, R, H BASTURKMEN \& S LOEWEN. 2001. Pre-emptive focus on form in the ESL classroom. TESOL Quarterly, 35(3): 407-432.

ELLIS, R, H BASTURKMEN \& S LOEWEN. 2003. Focussing on form in the classroom. Journal for Language Teaching, 37(2): 149-163.

GREEN, PS \& K HECHT. 1992. Implicit and explicit grammar: an empirical study. Applied Linguistics, 13(2): 168-84.

KRASHEN, SD. 1982. Principles and practice in second language acquisition. Oxford: Pergamon.

KRASHEN, SD. 1985. The input hypothesis: Issues and implications. London: Longman.

LITTLEWOOD, W. 1981. Communicative language teaching: An introduction. Cambridge: Cambridge University Press.

LYSTER, R. 1998. Negotiation of form, recasts, and explicit correction in relation to error types and learner repair in immersion classrooms. Language Learning, 48(2): 183-218. 
OLIVER, R. 2000. Age differences in negotiation and feedback in classroom and pair work. Language Learning, 50: 119-151.

RICHARDS, JC \& TS ROGERS. 1986. Approaches and methods in language teaching. Cambridge: Cambridge University Press.

ROBINSON, P. 1996. Learning simple and complex second language rules under implicit, incidental, rule-search, and instructed conditions. Studies in Second Language Acquisition, 18(1): 27-67.

SCHMIDT, RW. 1994. Implicit learning and the cognitive unconscious: Of artificial grammars and SLA. In Ellis, N (ed), Implicit and explicit learning of languages. London: Academic Press. 165-209.

SEEDHOUSE, P. 1997. Combining form and meaning. ELT Journal, 51(4): 336-344.

SHEEN, R. 2003. Focus on form - a myth in the making? ELT Journal, 57(3): 225-233.

WILLIAMS, J. 1999. Learner-generated attention to form. Language Learning, 49: 583-625.

\section{Biographic Note}

Diana Ayliff teaches in the Department of Language and Literature at the Somerstrand Campus of the Metropolitan University. Her teaching interests include second language teaching, academic English and Victorian Literature. Her research interest is in second language teaching and acquisition. Diana.ayliff@nmmu.ac.za. 


\section{APPENDIX A: CORRECTION AND RULE TASK}

a) On the next page you will find twelve sentences written by students who are learning English. There is one mistake (underlined) in each sentence.

b) Write the correct form of the underlined phrase in the space provided. It is not necessary to write out the whole sentence.

c) Then write down a grammar rule or an explanation that would help the student to avoid this mistake. Explain the rule as clearly as you can.

d) If you can not think of a rule, write a dash - (blank).

\section{EXAMPLES}

\begin{tabular}{|l|l|}
\hline $\mathbf{1}$ & $\begin{array}{l}\text { Its been raining again. } \\
\text { Correction: It's } \\
\text { Rule: It's stands for It is. You need an apostrophe to indicate the omission of } \\
\text { the letter } i .\end{array}$ \\
\hline $\mathbf{2}$ & $\begin{array}{l}\text { I have a german friend at university. } \\
\text { Correction: German } \\
\text { Rule: Proper nouns need a capital letter. }\end{array}$ \\
\hline $\mathbf{3}$ & $\begin{array}{l}\text { In the course we was shown how to do spreadsheets. } \\
\text { Correction: were shown } \\
\text { Rule: }-\end{array}$ \\
\hline
\end{tabular}

The following sentences were taken from a letter of a German student to an English friend.

1 As you know lives my aunt on a farm.

2 I spent last Easter with my aunt. Most of the time I've played tennis.

3 If you come to Munich next year, I show you the new sports centre.

4 It takes not very long to get there.

5 There is a farm near us. Do you like to ride horses?

6 If you do there'll be no problem, because I know the farmer for a long time.

7 Of course, we won't have to pay something for the ride.

8 Have I told you that my brother has got a new car? He drives more careful now than before.

The following sentences are taken from a statement given by a German student who saw a man steal a radio in a shop in London.

9 About half an hour ago a man was coming into the shop.

$10 \mathrm{He}$ had a very big nose and smoked a cigarette.

11 While the shop-keeper was fetching a radio from the backroom, the man, which was a thief, snatched a little cassette-recorder from the counter and ran out of the shop.

12 Outside he was arrested by an policeman. 